\title{
Seven-coordinated tantalum trichloride complex containing substituted pyrrolyl ligand: synthesis and characterization of $\left[\mathrm{NC}_{4} \mathrm{H}_{3}\left(\mathrm{CH}_{2} \mathrm{NMe}_{2}\right)-2\right]_{2} \mathrm{TaCl}_{3}$
}

\author{
Chong-Chin Zhou ${ }^{a}$, Jui-Hsien Huang ${ }^{a}, *$, Mei-Hua Wang ${ }^{b}$, Ting-Yu Lee ${ }^{\mathrm{b}}$, \\ Gene-Hsiang Lee ${ }^{\mathrm{c}}$, Shie-Ming Peng ${ }^{\mathrm{c}}$ \\ ${ }^{a}$ Department of Chemistry, National Changhua University of Education, Changhua 500, Taiwan, ROC \\ ${ }^{\mathrm{b}}$ Union Chemical Laboratories, Industrial Technology Research Institute, Hsinchu 300, Taiwan, ROC \\ ${ }^{\mathrm{c}}$ Department of Chemistry, National Taiwan University, Taipei 106, Taiwan, ROC
}

Received 11 January 2002; accepted 13 June 2002

\begin{abstract}
bis[2-(Dimethylaminomethyl)pyrrolyl]tantalum chloride (1) was prepared by treatment of the $\mathrm{TaCl}_{5}$ with 2 equiv. of [2(dimethylaminomethyl)pyrrolyl]lithium. The solid state structure of $\mathbf{1}$ shows the seven-coordinated tantalum atom, with a geometry corresponding to a pentagonal bipyramidal structure, in which two chlorine atoms occupy the axial position with the angle of $174.8(2)^{\circ}$. Furthermore, variable-temperature ${ }^{1} \mathrm{H}$ NMR spectra infer the fluxionality of the two chelating pyrrolyl ligands with an estimated energy barrier of $13.8 \mathrm{kcal} \mathrm{mol}^{-1}$. Compound 1 shows no catalytic activity toward ethylene polymerization even activated with MAO.
\end{abstract}

(C) 2002 Elsevier Science B.V. All rights reserved.

Keywords: Pyrrolyl; Tantalum chloride; Polymerization

\section{Introduction}

Early transition metal complexes have long been interested in their Lewis acidity, of which ancillary ligands are able to fine tune their electronic and steric properties [1]. Recent development of metallocene chemistry for the olefin polymerization is focused on the bis-cyclopentadienyl or mono-cyclopentadienyl ligand systems in cooperating with the metals of Group 4 and 5 [2]. The new types of olefin polymerization catalysts beyond metallocene have been reviewed recently by Gibson et al. [3], where alkoxide [4] and amido [5] ligands, monoanionic bidentate and tridentate aryl amine ligands [6] have been included. 2-(Dimethylaminomethyl) pyrrole [7] has been synthesized in 1947 but only very few examples of complexes containing the biand tri-dentate substituted pyrrolyl ligands were re-

\footnotetext{
* Corresponding author. Tel.: +886-4-723 2105x3531; fax: +886-47211190

E-mail address: juihuang@cc.ncuc.edu.tw (J.-H. Huang).
}

ported [8]. In continuing our studies of synthesizing substituted pyrrolyl metal complexes [9], here we report the results of synthesis, characterization, and reactivity of new tantalum complexes containing 2-(dimethylaminomethyl) pyrrole.

\section{Results and discussion}

The reaction of $\mathrm{TaCl}_{5}$ with 2 equiv. of $\mathrm{Li}\left[\mathrm{NC}_{4} \mathrm{H}_{3}\left(\mathrm{CH}_{2} \mathrm{NMe}_{2}\right)-2\right]$ in diethyl ether at $-78{ }^{\circ} \mathrm{C}$ afforded a seven-coordinated tantalum trichloride complex $\left[\mathrm{NC}_{4} \mathrm{H}_{3}\left(\mathrm{CH}_{2} \mathrm{NMe}_{2}\right)-2\right]_{2} \mathrm{TaCl}_{3}$ (1) in $83 \%$ yield (Scheme 1).

The reaction of $\mathrm{TaCl}_{5}$ with 1 or 3 equiv. of $\mathrm{Li}\left[\mathrm{NC}_{4} \mathrm{H}_{3}\left(\mathrm{CH}_{2} \mathrm{NMe}_{2}\right)-2\right]$ gives a mixture of unidentified products. ${ }^{1} \mathrm{H}$ NMR spectrum of complex 1 in $\mathrm{CDCl}_{3}$ at room temperature shows two sharp multiplets for the pyrrolyl protons at $\delta 6.68$ and 5.86. However, two very broad peaks were observed at $\delta 4.27$ and 3.10 , corresponding to the resonances of the methylene and 


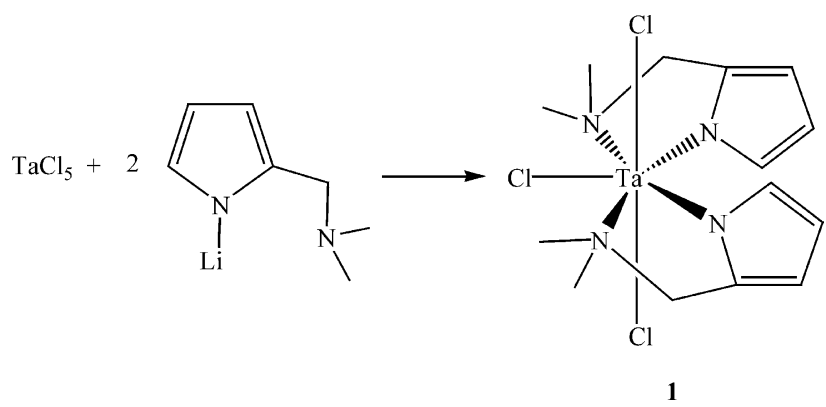

Scheme 1.

methyl group of $\mathrm{CH}_{2} \mathrm{NMe}_{2}$, respectively. As expected, complex 1 exhibits similar spectral feature of the ligand in the ${ }^{13} \mathrm{C}$ NMR spectrum at room temperature. However, the methyl group of $\mathrm{CH}_{2} \mathrm{NMe}_{2}$ is too broad to obtain $J_{\mathrm{CH}}$ coupling constant from ${ }^{13} \mathrm{C}$ NMR gateddecoupling experiment. A variable temperature ${ }^{1} \mathrm{H}$ NMR spectra of complex 1 were recorded between 60 and $50{ }^{\circ} \mathrm{C}$ in $\mathrm{CDCl}_{3}$ at $200 \mathrm{MHz}$ NMR spectrometer (Fig. 1). At lower temperature, the methylene and methyl protons of $\mathrm{CH}_{2} \mathrm{NMe}_{2}$ split into two doublets at $\delta \quad 4.5$ and 4.0 and two singlets at $\delta 3.5$ and 2.7,

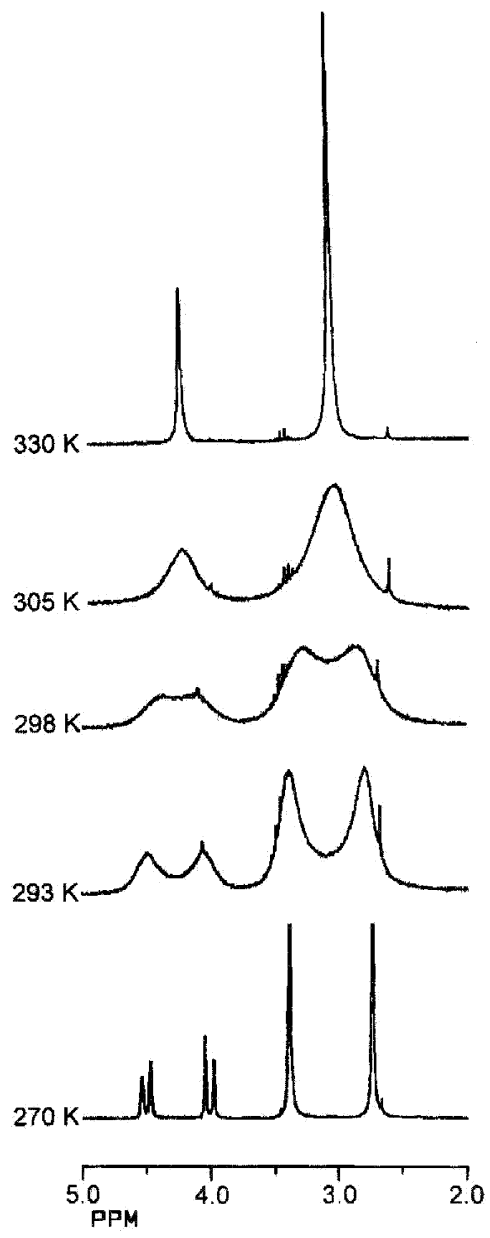

Fig. 1. The variable temperature ${ }^{1} \mathrm{H}$ NMR spectra of complex $\mathbf{1}$ in $\mathrm{CDCl}_{3}$ at $200 \mathrm{MHz}$ NMR spectrometer. respectively. On raising the temperature to $300 \mathrm{~K}$, the methylene and methyl resonances coalesce to two broad peaks, and eventually grow into two sharp peaks at $\delta$ 4.0 and 2.9, respectively. The phenomena could be resulted from the fluxionation of the two substitutedpyrrolyl ligands, as shown in Scheme 2, and the activation energy is estimated at approximately 13.8 $\mathrm{kcal} \mathrm{mol}{ }^{-1}[10]$. However, we are unable to eliminate the possibility of the fluxionality caused by the seven to six-coordinate conversion by dissociation of one $\mathrm{NMe}_{2}$ from complex 1 in solution.

Crystals for X-ray diffraction analysis were obtained from a diethyl ether solution of complex $\mathbf{1}$ at $-20{ }^{\circ} \mathrm{C}$. The X-ray crystallographic data are summarized in Table 1 and selected bond distances and angles are listed in Table 2. An ORTEP drawing is depicted in Fig. 2. The solid state structure of $\mathbf{1}$ contains a seven-coordinate tantalum atom, with a geometry corresponding to a distorted pentagonal bipyramidal structure. Two chlorine atoms occupy the axial positions with $\mathrm{Cl}(2)-\mathrm{Ta}-$ $\mathrm{Cl}(3)$ angle of $174.8(2)^{\circ}$ while the four nitrogen atoms of the two substituted pyrrolyl ligands and one chlorine atom compose the pentagonal plane. However, while viewing the structure of $\mathbf{1}$ along the $\mathrm{Ta}-\mathrm{Cl}(1)$ axis and placing the $\mathrm{Cl}(3)-\mathrm{Ta}-\mathrm{Cl}(1)$ as a perpendicular axis, the two nitrogen atoms of pyrrolyl are placing on the opposite site of the pentagonal plane with the bond angles of $\mathrm{Cl}(2)-\mathrm{Ta}-\mathrm{N}(1)$ and $\mathrm{Cl}(2)-\mathrm{Ta}-\mathrm{N}(3)$ at $97.8(5)$ and $83.1(5)^{\circ}$, respectively, and for the two dimethyl amino nitrogen atoms, bond angles of $\mathrm{Cl}(2)-\mathrm{Ta}-\mathrm{N}(2)$ and $\mathrm{Cl}(2)-\mathrm{Ta}-\mathrm{N}(4)$ are $80.1(4)$ and $102.5(4)^{\circ}$, respectively (Scheme 3).

The bond distances of the equatorial and axial $\mathrm{Ta}-\mathrm{Cl}$ are in the range of 2.36-2.38 $\AA$, which are comparable with the $\mathrm{Ta}-\mathrm{Cl}$ bond distances reported in the literature $[11,12]$. As expected, bond lengths of coordinated $\mathrm{Ta}-$ $\mathrm{N}$ (dimethylamino) (2.48(2) and 2.4(2) $\AA$ ) are much longer than those of $\sigma$-bonded $\mathrm{Ta}-\mathrm{N}$ (pyrrolyl) (2.06(2) and 2.04(2) A). To our knowledge, complex 1 is the first tantalum complex containing a bidentate $\eta^{1}$ pyrrolyl ligand characterized structurally.

A series of metathesis reactions have been carried out in order to synthesize tantalum alkyl or tantalum hydride complexes; unfortunately, the reactions of complex 1 with $\mathrm{RMgBr}\left(\mathrm{R}=\mathrm{Ph}, \mathrm{Me},{ }^{\mathrm{t}} \mathrm{Bu}\right), \mathrm{RLi}(\mathrm{R}=$ $\left.\mathrm{AlH}_{4}, \mathrm{H}, \mathrm{Me},{ }^{\mathrm{n}} \mathrm{Bu}, \mathrm{NEt}_{2}\right)$, or $\mathrm{RNa}\left(\mathrm{R}=\mathrm{OMe}, \mathrm{N}_{3}\right)$ result in inseparable mixture of products. Presumably, the two

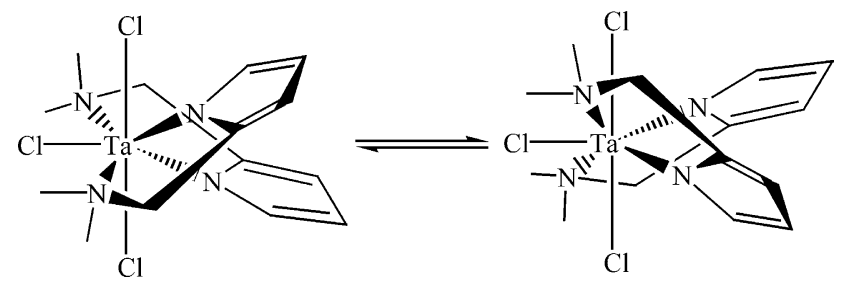

Scheme 2 
Table 1

Crystallographic data for complex 1

\begin{tabular}{|c|c|}
\hline Empirical formula & $\mathrm{C}_{16} \mathrm{H}_{27} \mathrm{Cl}_{3} \mathrm{~N}_{4} \mathrm{O}_{0.5} \mathrm{Ta}$ \\
\hline Formula weight & 570.72 \\
\hline Temperature (K) & $295(2)$ \\
\hline Wavelength $(\AA)$ & 0.71073 \\
\hline Crystal system & monoclinic \\
\hline Space group & $P 2_{1} / n$ \\
\hline \multicolumn{2}{|l|}{ Unit cell dimensions } \\
\hline$a(\AA)$ & $8.256(2)$ \\
\hline$b(\AA)$ & $15.098(3)$ \\
\hline$c(\AA)$ & $16.737(3)$ \\
\hline$\beta\left({ }^{\circ}\right)$ & $98.84(2)$ \\
\hline$V\left(\AA^{3}\right)$ & $2061.4(7)$ \\
\hline$Z$ & 4 \\
\hline$D_{\text {calc }}\left(\mathrm{Mg} \mathrm{m}^{-3}\right)$ & 1.839 \\
\hline Absorption coefficient $\left(\mathrm{mm}^{-1}\right)$ & 5.730 \\
\hline$F(000)$ & 1116 \\
\hline Crystal size (mm) & $0.50 \times 0.50 \times 0.20$ \\
\hline$\theta$ Range $\left({ }^{\circ}\right)$ & $1.83-25.00$ \\
\hline Reflections collected & 3628 \\
\hline Independent reflections & $3628\left(R_{\mathrm{int}}=0.0000\right)$ \\
\hline Absorption correction & semi-empirical from psi-scans \\
\hline Max/min transmission & $0.3581,0.2472$ \\
\hline Refinement method & $\begin{array}{l}\text { full-matrix least-squares on } \\
F^{2}\end{array}$ \\
\hline Data/restraints/parameters & $3628 / 2 / 213$ \\
\hline Goodness-of-fit on $F^{2}$ & 1.061 \\
\hline Final $R$ indices $[I>2 \sigma(I)]$ & $R_{1}=0.0876, w R_{2}=0.2180$ \\
\hline$R$ indices (all data) & $R_{1}=0.1617, w R_{2}=0.2478$ \\
\hline Extinction coefficient & $0.0004(4)$ \\
\hline $\begin{array}{l}\text { Largest difference peak and hole (e } \\
\AA^{-3} \text { ) }\end{array}$ & 4.528 and -5.294 \\
\hline
\end{tabular}

2-(dimethylaminomethyl)pyrrolyl ligands donate electrons toward the tantalum metal decreasing the nucleophilicity of the metal center.

The polymerization reactions catalyzed by complex $\mathbf{1}$, activated by MAO and $\mathrm{Al}\left({ }^{\mathrm{i}} \mathrm{Bu}\right)_{3}$, have been investigated under ethylene (150 psi) and propylene (90 psi) pressure. Surprisingly, no detectable activity was observed for the olefin polymerization reactions. A similar complex,

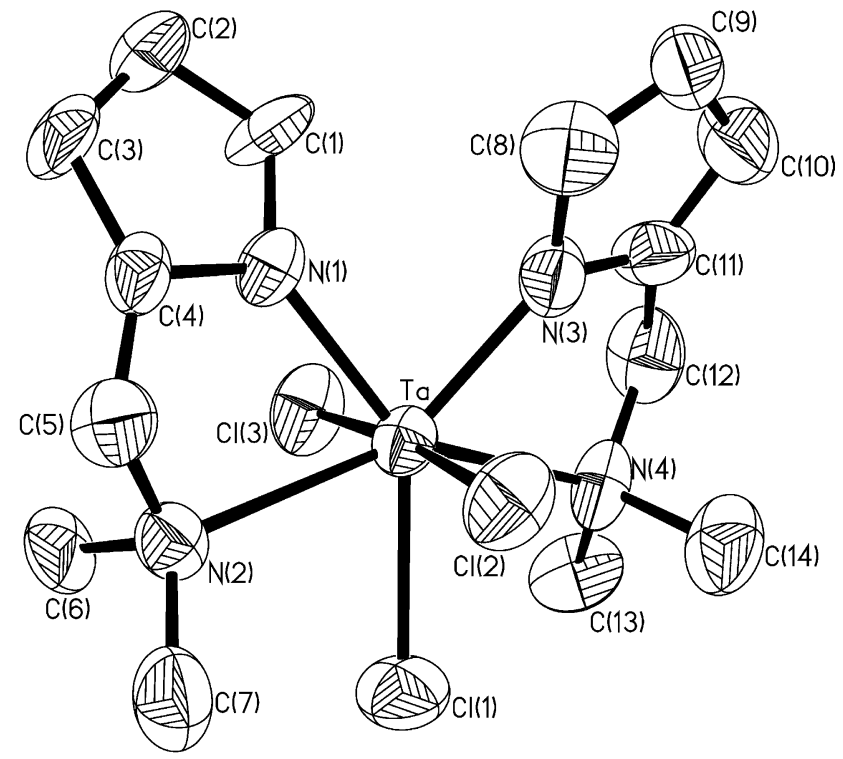

Fig. 2. The ORTEP drawing of complex $\mathbf{1}$. The thermal ellipsoids were drawn at the $50 \%$ probability level. The hydrogen atoms were omitted for clarity.

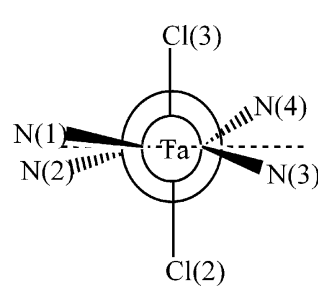

Scheme 3.

bis(benzylaminopyridinato)trichlorotantalum, published by K. Hakala and M. Polamo et al. shows good activity toward the ethylene polymerization [13]. The reaction procedure and conditions were listed in the supporting information.

Table 2

Selected bond distances $(\AA)$ and angles $\left(^{\circ}\right)$ for complex 1

\begin{tabular}{|c|c|c|c|c|c|}
\hline \multicolumn{6}{|l|}{ Bond distances } \\
\hline $\mathrm{Ta}-\mathrm{N}(3)$ & $2.04(2)$ & $\mathrm{Ta}-\mathrm{N}(1)$ & $2.06(2)$ & $\mathrm{Ta}-\mathrm{Cl}(3)$ & $2.367(5)$ \\
\hline $\mathrm{Ta}-\mathrm{Cl}(2)$ & $2.375(5)$ & $\mathrm{Ta}-\mathrm{Cl}(1)$ & $2.383(6)$ & $\mathrm{Ta}-\mathrm{N}(4)$ & $2.46(2)$ \\
\hline $\mathrm{Ta}-\mathrm{N}(2)$ & $2.48(2)$ & & & & \\
\hline \multicolumn{6}{|l|}{ Bond angles } \\
\hline $\mathrm{N}(3)-\mathrm{Ta}-\mathrm{N}(1)$ & 79.3(7) & $\mathrm{N}(3)-\mathrm{Ta}-\mathrm{Cl}(3)$ & $102.0(5)$ & & \\
\hline $\mathrm{N}(1)-\mathrm{Ta}-\mathrm{Cl}(3)$ & $84.0(5)$ & $\mathrm{N}(3)-\mathrm{Ta}-\mathrm{Cl}(2)$ & $83.1(5)$ & & \\
\hline $\mathrm{N}(1)-\mathrm{Ta}-\mathrm{Cl}(2)$ & $97.8(5)$ & $\mathrm{Cl}(3)-\mathrm{Ta}-\mathrm{Cl}(2)$ & $174.8(2)$ & & \\
\hline $\mathrm{N}(3)-\mathrm{Ta}-\mathrm{Cl}(1)$ & $138.2(5)$ & $\mathrm{N}(1)-\mathrm{Ta}-\mathrm{Cl}(1)$ & $142.4(5)$ & & \\
\hline $\mathrm{Cl}(3)-\mathrm{Ta}-\mathrm{Cl}(1)$ & $88.7(2)$ & $\mathrm{Cl}(2)-\mathrm{Ta}-\mathrm{Cl}(1)$ & $86.9(2)$ & & \\
\hline $\mathrm{N}(3)-\mathrm{Ta}-\mathrm{N}(4)$ & $68.4(6)$ & $\mathrm{N}(1)-\mathrm{Ta}-\mathrm{N}(4)$ & $139.0(7)$ & & \\
\hline $\mathrm{Cl}(3)-\mathrm{Ta}-\mathrm{N}(4)$ & $79.0(4)$ & $\mathrm{Cl}(2)-\mathrm{Ta}-\mathrm{N}(4)$ & $102.5(4)$ & & \\
\hline $\mathrm{Cl}(1)-\mathrm{Ta}-\mathrm{N}(4)$ & $74.4(5)$ & $\mathrm{N}(3)-\mathrm{Ta}-\mathrm{N}(1)$ & $142.8(6)$ & & \\
\hline $\mathrm{N}(1)-\mathrm{Ta}-\mathrm{N}(2)$ & $70.5(6)$ & $\mathrm{Cl}(3)-\mathrm{Ta}-\mathrm{N}(2)$ & $96.0(4)$ & & \\
\hline $\mathrm{N}(4)-\mathrm{Ta}-\mathrm{N}(2)$ & $147.9(6)$ & & & & \\
\hline
\end{tabular}




\section{Experimental}

All the reactions were performed using standard Schlenk techniques in an atmosphere of high purity nitrogen or in glove box. Ethyl ether was dried over $\mathrm{Na}-$ benzophenone ketyl and distilled before use. Methylene chloride was dried over $\mathrm{P}_{2} \mathrm{O}_{5}$ and distilled prior to use. 2,5-bis(dimethylaminomethyl)pyrrole [7] was prepared according to published literature and corresponding lithium salt was prepared by reacting ${ }^{n} \mathrm{BuLi}$ with the substituted pyrrole ligand. $\mathrm{CDCl}_{3}$ was degassed by using freeze-and-thaw method and dried over $4 \AA$ molecular sieves. ${ }^{1} \mathrm{H}$ and ${ }^{13} \mathrm{C}$ NMR spectra were collected on a Bruker AC200 and elemental analysis was performed on Perkin-Elmer CHN-2400.

\subsection{Preparation of $\left[\mathrm{NC}_{4} \mathrm{H}_{3}\left(\mathrm{CH}_{2} \mathrm{NMe}_{2}\right)-2\right]_{2} \mathrm{TaCl}_{3}$ (1)}

Tantalum chloride $(5.0 \mathrm{~g}, 13.9 \mathrm{mmol})$ was suspended in $20 \mathrm{ml}$ diethyl ether and cooled to $-78{ }^{\circ} \mathrm{C}$. To this suspension was added a solution of $\left[\mathrm{NC}_{4} \mathrm{H}_{3}\left(\mathrm{CH}_{2} \mathrm{NMe}_{2}\right)-2\right] \mathrm{Li}(3.63 \mathrm{~g}, 28.0 \mathrm{mmol})$ in $20 \mathrm{ml}$ diethyl ether over a period of $30 \mathrm{~min}$. The reaction mixture was allowed to warm to room temperature (r.t.) and stirred for $12 \mathrm{~h}$. The suspension was filtered through Celite and washed with $15 \mathrm{ml}$ methylene chloride in three times. The combined filtrate was reduced, and recrystallized at $-20{ }^{\circ} \mathrm{C}$. Dark crystals were isolated in $83 \%$ yield $(6.27 \mathrm{~g}) .{ }^{1} \mathrm{H} \mathrm{NMR}\left(\mathrm{CDCl}_{3}\right.$, r.t.): $\delta 6.68(\mathrm{~m}$, $\left.1 \mathrm{H}, \mathrm{NC}_{4} H_{3}\right), 5.86\left(\mathrm{~m}, 2 \mathrm{H}, \mathrm{NC}_{4} H_{3}\right), 4.27$ (br, s, 2H, $\left.\mathrm{CH}_{2} \mathrm{NMe}_{2}\right), 3.10$ (br, d, $\left.6 \mathrm{H}, \mathrm{NMe} e_{2}\right) .{ }^{13} \mathrm{C} \mathrm{NMR}\left(\mathrm{CDCl}_{3}\right.$, r.t.): $\delta 140.5$ (s, $C_{i p s o}$, pyrrolyl), $136.5\left(\mathrm{~d}, J_{\mathrm{CH}}=189 \mathrm{~Hz}\right.$, $C \mathrm{H}$ of pyrrolyl), $111.8\left(\mathrm{~d}, J_{\mathrm{CH}}=170 \mathrm{~Hz}, C \mathrm{H}\right.$ of pyrrolyl), $103.7\left(\mathrm{~d}, J_{\mathrm{CH}}=169 \mathrm{~Hz}, C \mathrm{H}\right.$ of pyrrolyl), $62.4\left(\mathrm{t}, J_{\mathrm{CH}}=141 \mathrm{~Hz}, \mathrm{CH}_{2} \mathrm{NMe}_{2}\right), 51.5\left(\mathrm{br}, \mathrm{CH}_{2} \mathrm{NMe}\right.$ ). Anal. Calc. for $\mathrm{C}_{14} \mathrm{H}_{22} \mathrm{~N}_{4} \mathrm{Cl}_{3} \mathrm{Ta} \cdot 0.5 \mathrm{Et}_{2} \mathrm{O}: \mathrm{C}, 33.67 ; \mathrm{H}$, 4.77; N, 9.82. Found: C, 33.14; H, 4.60; N, 10.82\%.

\subsection{X-ray structure determination of complex 1}

The crystals of $1 \cdot 0.5 \mathrm{OEt}_{2}$ were mounted on glass fibers using epoxy resin and transferred to a goniostat. Data were collected on a Nonius CAD4 four-circle diffractometer with graphite-monochromated Mo $\mathrm{K} \alpha$ radiation. A $\pi$-scan empirical absorption was applied. Using SHELXTL program on PC computer made the structure analysis. Structure was solved using the direct method and refined by full-matrix least-squares on $F^{2}$ values. Non-hydrogen atoms were refined anisotropically. Hydrogen atoms were fixed at calculated positions and refined using a riding mode. The crystal data are summarized in Table 1.

\section{Supplementary material}

Tables of crystallographic data for complex $\mathbf{1}$ and the olefin polymerization conditions and results (nine pages) are available from the authors on request. The crystallographic data can also be obtained at the Cambridge Structure Database.

\section{Acknowledgements}

We are grateful to the National Science Council (Taiwan) for supporting this research and the National Center for High Performance Computing for data base search.

\section{References}

[1] H. Yamamoto (Ed.), Lewis Acids in Organic Synthesis, WileyVCH, New York, 2000.

[2] For reviews see (a) R.F. Jordan, Adv. Organomet. Chem. 32 (1991) 325;

(b)H.H. Brintzinger, D. Fischer, R. Mülhaupt, B. Rieger, R.M. Waymouth, Angew. Chem., Int. Ed. Engl. 34 (1995) 1143; (c)P.C. Möhring, N.J. Coville, J. Organomet. Chem. 479 (1994) 1.

[3] G.J.P. Britovsek, V.C. Gibson, D.F. Wass, Angew. Chem., Int. Ed. Engl. 38 (1999) 428.

[4] (a) S. Fokken, T.P. Spaniol, H.-C. Kang, W. Massa, J. Okuda, Organometallics 15 (1996) 5069;

(b) H. Mack, M.S. Eisen, J. Chem. Soc., Dalton Trans. (1998) 917;

(c) A. van der Linden, C.J. Schaverien, N. Meijboom, C. Ganter, A.G. Orpen, J. Am. Chem. Soc. 117 (1995) 3008.

[5] (a) J.D. Scollard, D.H. McConville, J.J. Vittal, Organometallics 16 (1997) 4415;

(b) R. Baumann, W.M. Davis, R.R. Schrock, J. Am. Chem. Soc. 119 (1997) 3830.

[6] R.A. Gossage, L.A. van de Kuil, G. van Koten, Acc. Chem. Res. 31 (1998) 423.

[7] (a) W. Herz, K. Dittmer, J. Am. Chem. Soc. 69 (1947) 1698; (b) I.T. Kim, R.L. Elsenbaumer, Tetrahedron Lett. 39 (1998) 1087.

[8] (a) H. Drevs, A. Schmeiber, H. Hartung, U. Baumeister, Chem. Ber. 129 (1996) 853;

(b) S.A. Harris, J.T. Ciszewski, A.L. Odom, Inorg. Chem. 40 (2001) 1987;

(c) Y. Matsuo, K. Mashima, K. Tani, Organometallics 20 (2001) 3510 ;

(d) T. Dubé, S. Conoci, S. Gambarotta, G.P.A. Yap, G. Vasapollo, Angew. Chem., Int. Ed. Engl. 38 (1999) 3657;

(e) T. Dubé, S. Gambarotta, G.P.A. Yap, Organometallics 19 (2000) 115 ;

(f) T. Dubé, D. Freckmann, S. Conoci, S. Gambarotta, G.P.A. Yap, Organometallics 19 (2000) 209;

(g) T. Dubé, S. Conoci, S. Gambarotta, G.P.A. Yap, Organometallics 19 (2000) 1182;

(h) T. Dubé, M. Ganesan, S. Conoci, S. Gambarotta, G.P.A. Yap, Organometallics 19 (2000) 3716.

[9] (a) J.-H. Huang, P.-C. Kuo, G.-H. Lee, S.-M. Peng, J. Chin. Chem. Soc. 47 (2000) 1191;

(b) J.-H. Huang, L.-S. Chi, F.-M. Huang, P.-C. Kuo, C.-C. Zhou, G.-H. Lee, S.-M. Peng, J. Chin. Chem. Soc. 47 (2000) 895; 
(c) J.-H. Huang, H.-J. Chen, J.-C. Chang, C.-C. Zhou, G.-H. Lee, S.-M. Peng, Organometallics 20 (2000) 2647.

[10] H.C.L. Abbenhuis, M.H.P. Rietveld, H.F. Haarman, M.P Hogerheide, A.L. Spek, G. van Koten, Organometallics 13 (1994) 3259 .

[11] (a) H.C.L. Abbenhuis, N. Feiken, H.F. Haarman, D.M. Grove, E. Horn, A.L. Spek, M. Pfeffer, G. van Koten, Organometallics 12 (1993) 2227;

(b) H.C.L. Abbenhuis, N. Feiken, D.M. Grove, J.T.B.H. Jastr- zebski, H. Kooijman, P. van der Sluis, W.J.J. Smeets, A.L. Spek, G. van Koten, J. Am. Chem. Soc. 114 (1992) 9773;

(c) H.C.L. Abbenhuis, N. Feiken, H.F. Haarman, D.M. Grove, E. Horn, H. Kooijman, A.L. Spek, G. van Koten, Angew. Chem., Int. Ed. Engl. 30 (1991) 996.

[12] M. Polamo, M. Leskela, J. Chem. Soc., Dalton Trans. (1996) 4345.

[13] K. Hakala, B. Löfgren, M. Polamo, M. Leskelä, Macromol. Rapid Commun. 18 (1997) 635. 